physicist, the chief problems concern the accumulation of salts and lime, and high alkalinity with its deleterious effects on soil structure. Great progress has recently been made towards their solution, while other, and in many respects more difficult, plantphysiological problems associated with osmotic-stress values resulting from abnormally high salt concentrations in the soil solution are attracting increasing attention.

Soil-moisture relationships assume particular importance under irrigated agriculture, and have not been made easier for the layman to understand by the modern and very fruitful concept of using energy relations to characterize soil-moisture phenomena. The authors' achievement in explaining these phenomena simply and clearly, but adequately, is one of the best things in the book, which is almost certain to become a standard text-book on the subject.

\section{PANORAMA OF BRITAIN'S ECONOMY}

A Concise Economic History of Britain

From the Earliest Times to 1750. By Sir John Clap. ham. Pp. xvii + 324. (Cambridge: At the University Press, 1949.) 12s. 6d. net.

$\mathrm{O}$

all aspects of history, the economic, though not the most important, is the most fundamental, because it is concerned with the story of man's work, particularly in agriculture, trade and manufacture. It is concerned more with the ordinary man and the routine affairs of everyday life than with the lives of great men or the high spots of diplomacy, strategy or politics. Thus to the economic historian "the Norman Conquest is not so decisive an episode as it rightly seems to the general historian. It made no change in the economic resources of Britain or in its economic position in western Europe, and did not at once link it any more closely with other regions. The growing intimacy with the outer world that we notice after 1066 might have come in any event" (p. 69).

Economic activity is likened by Sir John Clapham to. the basement of man's house. In the course of ages this basement has provided, first for the privileged few and then for more, the opportunity to practise higher things. In a masterly survey the author examines this basement throughout the centuries, and has produced a most readable account, without sacrifice of accuracy and without entering into those incautious generalizations which are so dangerous a pitfall in the path of anyone writing a concise history. In broad majestic sweeps, spanning the centuries, he writes of villages and hamlets, of crafts and craftsmen, of gardens and orchards, of agriculture, industry and finance, of windmills and watermills, of merchants, apprentices and yeomen, and of turnips, clover and potatoes. Occasionally he spares time to pause so that we may make the acquaintance of some individual hitherto unknown to fame, as Odo the Catapult Man or Otho the Goldsmith. Or again, when illustrating the opportunities which were open to an able thirteenthcentury merchant, we are given a thumb-nail biography of William of Doncaster, citizen of Chester in the reign of Edward I. William had agents who bought wine in Gascony which he re-sold to the Court and the public, he sent wool over to Ipswich for the Flanders market, he traded with Ireland in corn, and he once did a big deal with the king in horseshoes and nails. As all successful traders did for centuries, he invested part of his fortune in land.

Sir John Clapham lectured during 1908-35 in the University of Cambridge on British economic history ; but he died before this book went through the press. Mr. John Saltmarsh, one of Clapham's former pupils, has prepared the text for the printers, and is to be congratulated on the excellent way he has carried out this task. This scholarly work, brilliantly written, and a marvel of condensation, is a fitting complement to the massive volumes of the author's "Economic History of Modern Britain". K. G. FENELON

\section{APPLIED ACOUSTICS}

Traité de prise de son

Par José Bernhart. (Collection de la radiodiffusion française.) Pp. 382. (Paris : Éditions Eyrolles, 1949.) 2,950 francs.

7 HIS book, on the use of the microphone in all forms of sound recording in the studio and the open air, is prefaced by the composer Arthur Honegger, who rightly says that the musician will here find, coded in scientific formulæ, results of acoustic science which he himself could only attain after a long hit-or-miss experience. The work is, in fact, addressed rather to the 'producer' and 'director' than to the technologist, though the data are presented in an imposing array of tables and graphs built on a truly scientific background of experiment. As the author points out, the métier of sound engineer unites art and technique. One feels as one reads that he, as head of the sound engineering department of Radio Diffusion Française, certainly knows what he is writing about.

There is, in fact, no other text in which can be found the fruits of so varied an experience in all forms of sound pick-up, covering as it does auditorium and studio acoustics, broadcasting, the film, directive properties of typical microphones, and stereophonic reproduction. Later sections deal with the properties of the ear and the possible distortions introdured by electro-acoustic systems, the directional properties of orchestral instruments in relation to the microphone, first as solo instruments and then in small ensembles, and finally the best microphone grouping for balance of power in recording a large orchestra. Then we have the sound montage for recording a single speaker or a complete drama; even how to produce 'noises off'. Nothing, in fact, escapes M. José Bernhart's all-embracing pen, whether it is the technique of 'mixing', of dynamic balance or of 'compression'. Finally, he suggests a course of training in critical listening and score-reading suitable for young technicians. Certainly an aspirant in this profession who had absorbed all the matter of this book could congratulate himself that only experience was required to make him expert.

The effect on the general reader of this mass of information is at first overwhelming, but a closer study will reveal that there is, in fact, some repetition, apparently in the attempt to make each section selfcontained. Set down in simplest musical and scientific terms, the whole could probably have been condensed to half its space. Nevertheless, M. Bernhart hólds the reader's interest to the end, ably seconded by his draughtsman and photographer. There are extensive bibliographies.
E. G. RICHARDSON 